\title{
SOCIO-ECONOMIC STATUS ITS INFLUENCE ON ACADEMIC INTEREST OF SECONDARY SCHOOL STUDENTS IN MEGHALAYA: A QUALITATIVE STUDY
}

\author{
TOBA LAMARE \\ Department of Education North-Eastern Hill University (NEHU), \\ Mawkynroh-Umshing Shillong 793022, India \\ E-mail address: tobalamare@gmail.com \\ ORCID: https://orcid.org/0000-0002-3568-9819 \\ EUODIA B. MYRTHONG \\ Department of Education North-Eastern Hill University (NEHU), \\ Mawkynroh-Umshing Shillong 793022, India \\ E-mail address: eubahun@gmail.com \\ ORCID: https://orcid.org/0000-0003-4066-1682
}

\begin{abstract}
Aim. The study intends to determine the influence of socio-economic status on academic interest of secondary school students in Meghalaya. The study was conducted in two districts of Meghalaya i.e., in East Jaintia Hills and West Jaintia Hills Districts.

Method. The researcher used sequential explanatory design for collecting the necessary information. The procedure of data collection was that the researcher constructed a semi-structured interview schedule whereby it was validated by the experts in the field of education. In order to determine the influence of socio-economic status on academic interest of secondary school students, the researcher conducted an in-depth interview on 50 secondary school students who were studying in class X. These students were selected purposively from two districts of Meghalaya. The interview was conducted at school premises and the necessary information collected from students was recorded and transcribed to obtain the results.

Results. Based on the interview conducted, the study found that socio-economic status did not influence the academic interest of the secondary school students; however, student's high aspirations, their interest in various subjects, their ambitions, determination and will power to work hard in their studies influence their academic interest.

Conclusion. Socio-economic status was not found to have influences on the academic interest of the secondary school students and on the whole the present study suggested for teachers and parents to work cooperatively in order to help students realize their goals and desires.
\end{abstract}

Key words: socio-economic status, interest, academic interest, secondary school students 


\title{
INTRODUCTION
}

\begin{abstract}
A ny country having dreams to flourish should give importance to education. Education is important because it helps to improve one's knowledge, skills and develops the personality and attitude. Faaz (2017) states that UNESCO laid emphasis on the importance of education, considering it as a major weapon to protect human rights in the world. An educated person has the proper sense about his or other's rights within a given society. Hence, the educational services, educational investment, and social importance of education play a significant role in an ever growing population, which was brought into the attention of educators, decision-makers and parents in improving school effectiveness (Meraz, 1983).
\end{abstract}

Student's academic interest is influenced by many factors including teachers, curriculum, school environment, socio-economic status, peer group, student's goals and the social environment which surrounds him. Socio-economic status is another factor which influences the academic interest of students. Traditionally, family status variables such as socio-economic status and parents' level of education have been regarded as predictors of children's academic achievement (Kainuwa \& Yusuf, 2013). Academic interest refers to the interest of students in education and other academic activities. It takes into account the intrinsic and extrinsic motivation. Intrinsic motivation involves goals and desire, ability, interest in subjects, determination and self-concept of the individual whereas extrinsic motivation encompasses reward, family and society. Academic interest also includes both inside and outside classroom activities which all students enjoy and participate in when they are at school. Students not only find their interest in learning the subjects but at the same time find it by participating in various activities like outdoor games and sports. Socio-economic status encompasses education, income, occupation of the family at the first place; moreover, it includes family size, property, social and health status, food and nutrition which the family can afford, transportation and a perso$\mathrm{n}$ 's access to goods and services. High socio-economic status refers to the students belonging to the families having high social standing, sufficient income, possessing their own facilities, properties and services. Average socio-economic status refers to the students belonging to the families who live an average life both socially and economically. This occurs because the family members hold average jobs or occupations and earning medium income, whereas Poor socio-economic status refers to the students belonging to families with low social position whose members are on daily wages and are hands to mouth earners.

The topic concerning academic performance of students is of great importance to every concerned parent. This is because the level of academic performance of any child goes a long way to determine the child's future career (Onoyase, 2015). Parents both literate and illiterate send their wards to school for a variety of reasons. These parents commit many resources towards the education of these children at different levels (Ezike, 2018). However, throughout the world, there are students belonging to wealthy families that receive 
a distinguished education and students belonging to low-income families that receive a substandard education (Carlisle \& Murray, 2015). These disparate educational experiences contribute to the academic achievement gap that has been a source of concern for decades.

\section{REVIEW OF RELATED LITERATURE}

There are various factors influencing academic interest of students. One factor is the socio-economic status. Socio-economic status of the family influences student's academic performance. In the study conducted by Ahmad-Kainuwa and Najeemah Binti Mohammad Yusuf (2013) it was found that parents' educational and socio-economic backgrounds influence the education of their children. Rana Muhammad Asad Khan, Nadeem Iqbal and Saima Tasneem (2015) indicated that highly educated parents have more influence on their children to achieve and perform well in their studies; moreover, highly educated parents usually show interest and care in their children's academic performance and their choice of subjects and careers while in secondary school. This possibly leads to better performance and achievements in studies. Thus, parents are in the position to put their children on the right course (Abdurrahman \& Madugu, 2014) especially at the early stage of development.

On the other hand, many studies revealed that students who belong to high socio-economic status and high parental educational background show better academic performance (Ahmar \& Anwar, 2013; Chandra \& Azimuddin, 2013; Singh \& Choudhary, 2015) and have good chances to be admitted to good professional courses (Tejas, Hemant, Pradnya, \& Chinmay, 2012; Raheem, 2015; Dahie, Mohamed, \& Moalim, 2016). The reason could be that of stable socio-economic status of a family which can brings comfort, positive attitude and healthy environment which leads to high academic achievements of the students (Saifi \& Mehmood, 2011; Ogunshola \& Adewale, 2012). Educated parents are assumed to create environment that facilitates learning (Darwish, 2016). Furthermore, Mary Nadenge Gabriel, Ngesu Lewis Muli, Isaac Muasya, Timothy Maonga \& Maira J. Mukhungulu (2016) in their study found that parental occupation and involvement in learning activities and effective parent-teacher relationship were also facilitators.

Academic interest is another factor that influences the academic achievement of the students. In the study conducted by Kpolovie, Joe \& Okoto (2014) the finding revealed that student's attitude to school and their interests in learning are significantly related. This is not surprising as the students with much better attitude to school are bound to be more interested in learning and more frequently be engaged in studying, using better information processing stiles in learning. Student's interest in a subject significantly influences their academic achievement in the subject (Essien, Akpan, \& Obot, 2015). It was also found that students' interest in learning and attitude towards school jointly and separately predict academic performance (Kpolovie, Joe, \& Okoto, 2014). Yu-Je Lee, Chia-Hui Chao and Ching-Yaw Chen (2011) in their study found 
that both interests in learning and learning hours have a positive and significant interactive influence on the learning outcomes. Thus, improvement of student's interest in learning and attitude to school could contribute to boosting their performance academically.

\section{SIGNIFICANCE OF THE STUDY}

The present study was conducted to examine the influence of socio-economic status on academic interest of secondary school students. The findings of the study are of great importance as it will give a guiding principle to several entities. It should allow teachers to organise their procedures of teaching systematically and to be able to capture the students' interest in learning. Parents, the motivators and a source of inspiration, will become more aware of their role and that of the parenting skills. Finally, it should allow policy makers to satisfy the essential needs of the students in order to allow young students to fulfil their aspirations. It is essential to study the influence of socio-economic status on academic interest of secondary school students because a pleasant environment at home and at school must be created in order for students to develop an interest in learning and help in improving their academic interest wisely.

\section{OPERATIONAL DEFINITIONS OF THE TERMS USED}

Socio-economic status - it refers to the position of a person in the society; their position and status are being compared in relation with others based on their educational attainment, occupational level and income.

Interest - it refers to the feeling of a person in a specific task or activity that causes them to devote their attention to that task.

Academic interest - it refers to student's interest in education and school life. Academic interest of the students involves intrinsic motivation such as goals and desire, ability, interest in subjects, determination and self-concept of the individual and extrinsic motivation such as reward, family and society.

Secondary school students - refers to all students studying in Classes IX and X in Jaintia Hills Districts.

\section{DELIMITATION OF THE STUDY}

The present study was delimited to Class X students of East Jaintia Hills District and West Jaintia Hills District of Meghalaya.

\section{METHODOLOGY OF THE STUDY}

This study is a part of a broader dissertation entitled "Influence of Socio-economic Status on Academic Interest and Academic Achievement of the 
Secondary School Students in Meghalaya" which follows an explanatory sequential mixed methods design (also called a two-phase model; Creswell \& Clark, 2011, p. 542) whereby a procedure for collecting, analyzing, and "mixing" both quantitative and qualitative methods in a single study to understand a research problem. It consists of first collecting quantitative data and then collecting qualitative data to help explain or elaborate on the quantitative results.

The samples of the study included 50 secondary school students of East Jaintia Hills District and West Jaintia Hills District in Meghalaya.

In order to draw the required samples for the study, the researcher employed a purposive sampling technique for this current study. These students were selected from the representative sample in the quantitative study based on the different socio-economic status groups.

The instrument used in carrying out the study was a scheduled interview prepared by the researcher to study the influence of socio-economic status on academic interest of secondary school students; an appropriate recorder was used to record the necessary information delivered by students. The prepared interview scheduled was used for collecting necessary information from 50 secondary school students included both males and females.

Research question: What is the influence of socio-economic status on academic interest of secondary school students?

\section{ANALYSIS AND INTERPRETATION OF DATA}

The data collected from the interviews with students were analysed using thematic analysis method. In this method the researcher closely examined the data (transcribed interviews) to identify common themes that came up repeatedly. The analysed data is reported and interpreted on the basis of the stated objective.

Objective of the Study: the present study has only one objective which is to examine the influence of socio-economic status on academic interest of secondary school students.

In order to study the influence of socio-economic status on academic interest of secondary school students, data was collected from 50 secondary school students based on the different levels of socio-economic status (high socio-economic status, above average socio-economic status, average socio-economic status, below average socio-economic status and poor socio-economic status) through a prepared scheduled interview. The interview conducted was transcribed and presented on the basis of four themes: student's aspiration, ability and self-concept, interest in subjects and future course of study.

Theme I. Student's aspiration- this refers to the aim and ambition of students which they want to achieve in their lives. From the interview conducted it was found that secondary school students have high aspirations for their future. Many of them set high goals for themselves as they desire to do well in life and improve the economic growth of their family. Some of the goals and 
desires that the students aspire to achieve include those of becoming nurses, engineers, doctors, lawyers, pilots, officers, designers, architect, teachers, policemen and businessmen.

\section{Table 1}

Quotes from the students' interviews

Sub-theme I: Student's aim Quotations

Student belonging to

high SES

Student 1: belonging to above average SES

Student 2: belonging to above average SES

Student 1: belonging to average SES

Student 2: belonging to average SES

Student 3: belonging to average SES

Student 1: belonging to below average SES

Student 2: belonging to below average SES Student 3: belonging to below average SES Student 1: belonging to Poor SES

Student 2: belonging to "I want to become a lawyer. I want to become educated Poor SES

Source: recordings of students-own research

From the statements of the students it was observed that they have high aspirations. It may be noted that the students belonging to below average socio-economic status and poor socio-economic status also have high aspirations for their future like their counterparts belonging to high, above average and average socio-economic statuses. Furthermore, from the interview conducted it was found that the main reasons for high aspiration is that they want 
to be successful in life, to get admitted to good colleges, to get better jobs, to be able to support their families and to contribute towards the society. Therefore, from the interview conducted it can be concluded that student's aspiration influences their academic interest.

Theme II. Ability and Self-concept - another factor that was found to influence the academic interest of the secondary school students was their ability and self-concept. The interview conducted revealed that the students have the abilities and determination to do well in their studies.

Table 2

Quotes from the students' interviews

\begin{tabular}{ll}
\hline $\begin{array}{l}\text { Sub-theme II: } \\
\begin{array}{l}\text { Determination and } \\
\text { perseverance }\end{array}\end{array}$ & Quotations \\
\hline $\begin{array}{l}\text { Student belonging } \\
\text { to high SES }\end{array}$ & $\begin{array}{l}\text { "In my selection I didn't perform well as I spent only 2 to 3 } \\
\text { hours in a day and sometimes I did not get time to study also } \\
\text { because my mother gave birth when I was preparing my selection } \\
\text { examination. She got operated and she could not do the work } \\
\text { at home that is the main reason which makes me show poor } \\
\text { performance in this selection examination. But I will do well for } \\
\text { the final examination because I aim to get good marks." }\end{array}$
\end{tabular}

Student belonging to "I prepare well because I am very ambitious and even my parents above average SES also have high expectation from me........I never waste my time...... From my side I really want to excel in this class X examination. I consider my class $X$ as very important because through this I will be able to choose my future study and career. I don't face many problems in my studies but in social studies I really find problems. I have to concentrate more in this subject."

Student belonging to "I spend more time in my studies because I want to get good average SES marks especially to get distinction in all subjects..... In the selection also I perform well only but I still want to improve some more because I want to achieve my aim in life."

Student belonging to "I prepare well because I am very ambitious and even my parents below average SES also have high expectation from me. I used to study every day. I never waste my time...... From my side I really want to excel in this class $X$ examination. I consider my class $X$ as very important because through this I will be able to choose my future study and career. I don't face many problems in my studies but in social studies I really find problems. I have to concentrate more in this subject."

Student belonging to "I didn't go for tuition because I never go from before I can study Poor SES alone without the help of a tutor. My parents were saying if I need to go for tuition they can send me but I don't want and moreover one of my brother is in class XI science so if I have any doubts I used to ask him."

Source: recordings of students-own research 
As reported by the students it was found that the students belonging to different socio-economic statuses are aware of their abilities and expectations. It was also found that the students have high self-concept of themselves. Further, from the study conducted it was found that the they were capable and hardworking as many of them are ambitious and motivated to obtain distinction in all subjects. It was also found that their parents have high expectations from their children. In reference to the interview conducted it was drawn out that the students do face problems relating to certain subjects nevertheless they were determined to put extra efforts with or without remedial help (tuition) as observed in the case of the students belonging to the different socio-economic status groups.

Theme III. Interest in Subjects - in the present study, secondary school students indicated that they have interests related to different subjects (science and technology, mathematics, English, social studies, Khasi (mother tongue) and health education). The interview conducted revealed that the interest in the subjects arises because of intrinsic and extrinsic motivations.

Table 3

Quotes from the students' interviews

Sub-theme III: Various Quotations

subjects in school

Student belonging "I like science subject especially physics and chemistry. I found the to high SES subject interesting and enjoying to me."

Student belonging "I like science subject because I want to study MBBS and my aunt's

to above average children are also inspire me so much and they are the ones who guides SES me in my studies and if I have any problem also they used to teach me because they both study MBBS. I get motivated because of them."

Student 1: belonging "I like science and mathematics. Maths is difficult but I like both of to average SES these subjects because these subjects will guide me in the future." Student 2: belonging "I like all the subjects but Khasi (mother tongue) I like the most to average SES because I used to get distinction in this subject."

Student 1: belonging "I like mathematics and science subjects. I like maths because I don't to below average have to read but I just need to practice and I solve the sum easily and SES for science it's very interesting for me and I learn so many things about our organs in the body and the diseases and the way to heal them and science helps us to understand the world around us."

Student 2: belonging "The subjects I like the most are maths and science. They are of to below average course difficult subjects but I like these subjects. Teachers are very SES encouraging no matter what the difficulties. But maths is not that difficult for me."

Student 1: belonging "I like mathematics, science and English especially maths I find it to Poor SES like playing a game. I don't have any difficulties in maths. I found maths as an enjoyable subject."

Student 2: belonging "I like all subjects because our teachers teach us very well and to Poor SES from my side I am very attentive I concentrate properly in the class. We get times to discuss our doubts with our teachers as our teachers are very encouraging and ready to lend a hand."

Source: recordings of students-own research 
During the interview conducted majority of students belonging to the different socio-economic status expressed that they have a strong interest for science and mathematics subjects. The reasons for their interest in these subjects because they found these subjects important for their future career and also due to the support and influence of their family members. Other reasons were that their teachers could explain the lessons very well and teachers themselves were very encouraging, supportive and most importantly many students have a strong desire to pursue science stream. However, few students reported they didn't have learning capacities in science and mathematics because these subjects are difficult to score good marks. Therefore, interest in subjects is influencing the academic interest of the secondary school students.

Theme IV. Future course of study - Future course of study is one more factor found to influence academic interest of the students. It means a studen$t^{\prime}$ s preference for the type of course to pursue according to their abilities and capacities. The future courses of study where students have mentioned about are arts stream, science stream and commerce stream. Student's preference for future course of study is also very much depends on the financial support from their families which they belong to.

Table 4

Quotes from the students' interviews

\begin{tabular}{|c|c|}
\hline $\begin{array}{l}\text { Sub-theme IV: Arts, } \\
\text { Science and Commerce }\end{array}$ & Quotations \\
\hline $\begin{array}{l}\text { Student belonging to } \\
\text { high SES }\end{array}$ & $\begin{array}{l}\text { "I would like to choose science stream because I am } \\
\text { planning to study nursing when I finish class XII." }\end{array}$ \\
\hline $\begin{array}{l}\text { Student } 1 \text { : belonging } \\
\text { to above average SES }\end{array}$ & $\begin{array}{l}\text { "I would like to choose arts stream because I am not } \\
\text { interested in other two (science and commerce) streams." }\end{array}$ \\
\hline $\begin{array}{l}\text { Student } 2 \text { : belonging } \\
\text { above average SES }\end{array}$ & $\begin{array}{l}\text { "I would like to choose science stream because I am } \\
\text { interested in science subject." }\end{array}$ \\
\hline $\begin{array}{l}\text { Student belonging to } \\
\text { average SES }\end{array}$ & $\begin{array}{l}\text { "I will choose arts stream because I cannot go for science } \\
\text { stream because I find difficulties in maths and science } \\
\text { subjects." }\end{array}$ \\
\hline $\begin{array}{l}\text { Student belonging to } \\
\text { below average SES }\end{array}$ & $\begin{array}{l}\text { "I would like to choose commerce stream to study for } \\
\text { B.com and M.com." }\end{array}$ \\
\hline $\begin{array}{l}\text { Student belonging to } \\
\text { Poor SES }\end{array}$ & $\begin{array}{l}\text { "I would like to choose science stream because science } \\
\text { subject is important in order to achieve my dream." }\end{array}$ \\
\hline
\end{tabular}

Source: recordings of students-own research

As observed from the statements of the students belonging to different socio-economic statuses it is evident that secondary school students have their own choices and preferences for their future course of study according to their own capacities and preferences. It was observed that most students belonging to high, above average and poor socio-economic status stated that they have an interest to pursue science stream after they finish class $X$ and further stated that they found science subject very important for their future prospect. However 
some students belonging to above average and average socio-economic status they have stated that they would like to choose for an arts stream afterwards because they found science subject very difficult for them. Whereas students belonging to below average socio-economic status expressed that they would prefer commerce stream because they have their own planning in no doubt and revealed they have other plans for their future in choosing this course when they finish their master degree (M.com).

\section{RESULTS}

The results of the study indicated that some students belonging to below average socio-economic status and poor socio-economic status also have high aspirations for their future prospect, just like their counterparts belonging to high, above average and average socio-economic statuses since they want to be successful in life, to get admission in to good colleges, to get a better jobs, to be able to support their families and to contribute towards the society. It was also found that many students have high self-concept; they were capable and hardworking because many of them set higher dreams towards achieving success. The finding of the study also revealed that, many students belonging to different socio-economic statuses have a strong interest for science and mathematics subjects and hence desire to pursue science stream whereas some students expressed they desire for an arts stream and commerce stream since they find science subject difficult for them.

\section{CONCLUSION}

In short, the study highlighted that socio-economic status was not found to have influence on the academic interest of the secondary school students but student's high aspirations, their interest in various subjects, their ambitions, determination and will power to work hard in their studies influences their academic interest. Therefore, the researcher recommended that in order to achieve good academic outcomes, it is essential for the students to be devoted and earnest towards their studies. Students should be intrinsically motivated to learn and aspire high towards accomplishing their goals. The home environmental conditions should be peaceful and pleasant and parents should be the source of inspiration and support. Teachers should be friendly in attitude and should implement various teaching techniques to enhance learning and make learning processes advantageous for all.

\section{ACKNOWLEDGEMENT}

First of all, I would like to express my thankfulness to The Almighty God for His continual help and never leaving me throughout my life. I would also 
like to acknowledge two most important individuals Dr. Euodia B. Myrthong my supervisor and Welbirthstone L. Nonglait, my close friend, for their non-stop support and directions. Anytime I call for help they were always readily available for me in completing this manuscript and making it a success.

\section{REFERENCES}

[1] Abdurrahman, M. S., \& Madugu, A. (2014). Parental involvement and interest on senior secondary school students' mathematics achievement in Kebbi State, Nigeria. International Journal of Advancements in Research \& Technology, 3(12), 14-30.

[2] Ahmar, F., \& Anwar, E. (2013). Socio economic status and its relation to academic achievement of higher secondary school students. IOSR Journal of Humanities and Social Science (IOSR-JHSS), 13(6), 13-19.

[3] Carlisle, B. L., \& Murray, C. B. (2015). Academic performance, effects of socio-economic status on. International Encyclopaedia of the Social \& Behavioral Sciences, 1(2), 43-48.

[4] Chandra, R., \& Azimuddin, S. (2013). Influence of socio economic status on academic achievement of secondary school students of Lucknow City. International Journal of Scientific \& Engineering Research, 4(12), 1952-1960.

[5] Creswell, J. W. (2014). Research design Qualitative, Quantitative and Mixed Methods Approaches ( $4^{\text {th }}$ ed.). New Delhi: 1100044. SAGE Publications Asia-Pacific Pte Ltd.

[6] Dahie, A. M., Mohamed, M. O., \& Moalim, A. A. (2016). Socio-economic status and academic achievement at secondary schools in Mogadishu-Somalia. International Journal in Management and Social Science (Impact Factor- 4.358), 04(01), 300-313.

[7] Darwish, S. A. (2016). The role of socioeconomic factor in promoting higher education in the State of Kuwait. International Education Studies, 9(6), 1-14. DOI: http://dx.doi.org/10.5539/ ies.v9n6p1.

[8] Essien, E. E., Akpan, O. E., \& Obot, I. M. (2015). Students' interest in social studies and academic achievement in tertiary institutions in cross river state, Nigeria. European Journal of Training and Development Studies, 2(2), 35-40.

[9] Ezike, B. U. (2018). Classroom environment and academic interest as correlates of achievement in senior secondary school chemistry in Ibadan South West Local Government Area, Oyo State, Nigeria. Global Journal of Educational Research, 17, 61-71. https://dx.doi.org/10.4314/ gjedr.v17i1.9.

[10] Faaz, M. (2017). A study of intelligence, socio-economic status and attitude towards science in relation to academic achievement among upper primary school students of Western Uttar Pradesh (Ph.D. Thesis). Aligarh Muslim University, Aligarh.

[11] Gabriel, M. N., Muli, N. L., Muasya, I., Maonga, T., \& Mukhungulu, M. J. (2016). Parental socio-economic status and students' academic achievement in selected secondary schools in urban informal settlements in Westlands Division, Nairobi County. International Journal of Education and Social Science, 3(1), 43-55.

[12] Kainuwa, A., \& Yusuf, N. B. M. (2013). Influence of socio-economic and educational background of parents on their children's education in Nigeria. International Journal of Scientific and Research Publications, 3(10), 1-8.

[13] Khan, R. M. A., Iqbal, N., \& Tasneem, S. (2015). The influence of parent's educational level on secondary school student's academic achievements in District Rajanpur. Journal of Education and Practice, 6 (16), 76-79.

[14] Kpolovie, P. J., Joe, A. I., \& Okoto, T. (2014). Academic achievement prediction: role of interest in learning and attitude towards school. International Journal of Humanities Social Sciences and Education (IJHSSE), 1(11), 73-100.

[15] Lee, Y. J., Chao, C. H., \& Chen, C. Y. (2011). The influences of interest in learning and learning hours on learning outcomes of vocational college students in Taiwan: using a teacher's instructional attitude as the moderator. Global Journal of Engineering Education, 13(3), 140-153.

[16] Meraz, G. M. (1983). A study of the relationship of socioeconomic status and student perceptions of school effectiveness to academic achievement of engineering students (Master of Arts Thesis). 
Western Kentucky University Bowling Green, Kentucky.

[17] Ogunshola, F. \& Adewale, A.M. (2012).The effects of parental socio-economic status on academic performance of students in selected schools in Edu Lga of Kwara State Nigeria. International Journal of Academic Research in Business and Social Sciences, 2(7), 230-239.

[18] Onoyase, A. (2015). Academic performance among students in urban, semi urban and rural secondary schools counselling implications. Developing Country Studies, 5(19), 122-126.

[19] Raheem, B.O.A. (2015). Parent's socio-economic status as predictor of secondary school students' academic performance in Ekiti State, Nigeria. Journal of Education and Practice, 6(1), 123-128.

[20] Saifi, S., \& Mehmood, T. (2011). Effects of socioeconomic status on student's achievement. International Journal of Social Sciences and Education, 2(1), 119-128.

[21] Singh, P., \& Choudhary, G. (2015).Impact of socioeconomic status on academic-achievement of school students. An investigation International Journal of Applied Research, 1(4), 266-272.

[22] Tejas, G. P., Hemant, M. B., Pradnya, G. A., \& Chinmay, S. J. (2012).A study of socio-economic status and parental educational background of first year medical students in medical college Bhavnagar. International Research Journal of Pharmacy, 3(9), 253-255. 